\title{
Event Sponsorship by Alcoholic and Non-Alcoholic Drinks Businesses in India
}

\author{
Miguel Moital, Julie Whitfield and Caroline Jackson \\ School of Tourism, Bournemouth University, UK \\ Arjun Bahl \\ Crayon Events, New Delhi, India
}

\section{Abstract}

Purpose: This paper examines event sponsorship decision-making by the Indian drinks industry, comparing the non-alcoholic and alcoholic drinks sectors.

Design/Methodology/Approach: Data regarding event sponsorship activity, perceptions of event sponsorship, motives to sponsor, form of investment and structure of sponsorship was obtained from a sample of 61 drinks producers in India through a questionnaire. MannWhitney and Logistic Regression were employed to compare the alcoholic and the nonalcoholic sectors.

Findings: The results suggest that the alcohol and non-alcohol drinks sectors sponsored a similar level of events, but in investment volume terms, sponsorship from the non-alcoholic sector is far greater than that of the alcoholic sector. While the two sectors are similar in many ways, the emphasis placed on certain motives for sponsoring events was different, with alcoholic drinks businesses placing greater importance on reaching niche audiences and increasing media coverage than non-alcoholic ones.

Research limitations/Implications: A limited number of areas of the sponsorship decisionmaking process were covered, yet the study provides insights in to the decision-making of one of the key sponsoring industries: the drinks industry.

Practical implications: Securing sponsorship is becoming more difficult and complex. By understanding how sponsors make decisions, including potential variations between companies within an industry, event organisers will be in a better position to tailor sponsorship proposals, enhancing the likelihood of obtaining the desired sponsorship contracts.

Originality/value: Most sponsor decision-making research focuses on how sponsorship decisions can be improved so that it works better for the sponsor. This paper, in contrast, emphasises that by understanding how clients make decisions (i.e. sponsors), sellers (i.e. the sponsored) will be in a better position to win over competition and secure the desired sponsorship deals.

Keywords: Sponsorship, Event, Drinks Industry, Alcohol, India

\section{PUBLISHED IN}

Moital, M., J. Whitfield, Jackson, C. and Bahl, A., 2012. Event Sponsorship by Alcoholic and Non-Alcoholic Drinks Businesses in India International Journal of Contemporary $\mathrm{H}$ ospitality M anagement, 24 (2), 289-311 D O I 10.1108/ 09596111211206187 


\title{
Event Sponsorship by Alcoholic and Non-Alcoholic Drinks
}

\author{
Businesses in India
}

\section{Introduction}

The fundamental premise of any event is to bring together the purveyor of a message with its recipients, and thus make contact with a target audience. From product launches, corporate disclosure, to sporting events and national celebrations, all pass a message to a specific subset of the populous. The same principle applies to marketing. Whether concerned with price, quality, benefits or maintaining brand awareness, companies aim to convey a message to a target audience regarding the good or service they offer through the use of marketing. In doing so, many organisations have linked their name and/or products with events, and thus 'event sponsorship' has become a popular phenomenon (Bowdin et al., 2011). Event sponsorship is defined as "a commercial agreement by which a sponsor, for the mutual benefit of the sponsor and sponsored party, contractually provides financing or other support" (International Chamber of Commerce, 2003, p.2).

Almost 20 years of Indian economic liberalization have been epochal on the lives and attitudes of Indian society (Sinha, 2007). India's Gross Domestic Product has shown some of the largest growth rates in the world over the past years (Kazmin, 2009). It is estimated that approximately 300 million people have escaped extreme poverty due to economic liberalization; approximately 10 million Indians are now considered as upper class, and approximately 300 million as part of the rapidly increasing middle class (World Fact Book, 2009). According to Sinha (2007, p.2), "the opening up of the economy has opened up the minds of the people". Although as a developing country, India is culturally very different from the West, with economic liberalisation, the country is witnessing a cultural re-ordering of its socio-cultural value system (Batra et al., 2000). The economic expansion has been accompanied by the creation of a much larger middle class (Das, 2001; World Bank, 2006) and a 'Westernisation' of the country (Khairullah and Khairullah, 2005). A new generation of young Indians, more than 500 million Indians are below the age of 21 years and its median age is 25 years (Sinha, 2007), are struggling to embrace Western consumerism against the values of self-denial instilled through religious belief (Dhillon, 2005). However, 'Westernisation' has had a particularly significant impact on the nation's drinking habits, notably a greater acceptance towards alcohol consumption. As rigorous restrictions on advertising alcohol exist, event sponsorship has provided an alternative way of communicating with target markets.

According to the European Sponsorship Association (ESA, 2007), one of the common ways to initiate a sponsorship relationship is through those looking to obtain sponsorship to approach potential sponsors. In any case, irrespective of whether it is the sponsor or the 
sponsored that seeks a sponsorship opportunity, event managers who hold a detailed understanding of the sponsor's decision-making process are in a better position to succeed. This knowledge could improve event managers' ability to tailor their sponsorship proposals to the needs of potential sponsors, thus increasing their probability of securing the desired sponsorship deals. Consequently, understanding to what extent the specific context in which sub-sectors of an industry affects event sponsorship decision-making could be valuable for event organisers. This paper has two objectives:

1. To examine event sponsorship perceptions, motives and activity of Indian drinks businesses;

2. To compare sponsorship decision-making across two sub-sectors of the drinks industry: non-alcoholic and alcoholic.

\section{Marketing, branding and event sponsorship}

Event sponsorship is inextricably linked to marketing and brand awareness. Marketing focuses on relationship building and retention of customers to engender positive perceptions (Parvatiyar and Sheth, 1997). These perceptions formed by individuals concerning an organisation, its products, services and/or performance are referred to as 'brand awareness'. Brand awareness provides the foundation upon which consumers build a bond with a product or service (Aaker 1991; Weilbacher, 1995). To be successful, a brand must become identifiable so that the consumer perceives it as relevant, unique, adding value and matching their needs. This branding must be communicated (Chernatony et al., 2011; Keller, 2007); one such form of communication is that of event sponsorship.

Event sponsorship occurs for a multitude of reasons, but two common reasons are: (1) to raise brand awareness, and (2) to establish and/or alter brand image (Cornwell and Maignan, 1998; Gwinner, 1997). These reasons have been theorised through the development of customerbased brand equity, defined as the differential effect of brand knowledge on a consumer's purchasing decision (Keller, 2007). In Keller's conceptualization, brand knowledge is a product of both brand awareness and the images inextricably linked with that awareness. "In particular, the favourability, strength, and uniqueness of the brand associations play a critical role in determining the differential response" (Keller, 1993, p. 8). Event sponsorship provides the medium to broaden both brand awareness and associated images. In doing so it can increase an organisations competitive advantage by improving the organisations brand image, prestige and credibility through the support of events that their target market finds appealing and from which the desired positive emotions are created (Cornwell et al., 2001; Roy and Cornwell, 2003). Event sponsorship therefore serves as a brand-building tool because it leverages secondary brand associations, thus linking the brand with another entity (e.g. the sponsored event), and consumers infer the brand shares associations with that entity (Keller, 1993; Roy and Cornwell, 2003). Sponsorship has been utilised to combat rising advertising costs, the clutter and fragmentation of media, the advancement of technology, changing government policy and changing consumer lifestyles (Meenaghan, 1983; Meenaghan, 1991; 
Sneath et al., 2005). Sponsorship is regarded as one the most rapidly growing areas of marketing (Dolphin, 2003; Meenaghan, 2001).

\section{Sponsorship decision-making research}

Many different areas of the sponsorship decision-making process have been researched. However, the depth of understanding has been hampered by the reluctance of sponsors to disclose information regarding their own decision-making process (Fan and Pfitzenmaier, 2002). Perhaps due to its importance and relatively low degree of sensitivity, several studies have attempted to understand the general benefits sponsors seek to achieve from sponsorship (Fan and Pfitzenmaier, 2002; O'Hagan and Harvey, 2000). A number of these studies have focused on motives in general, that is, they did not focus on a specific type of motive (e.g. Apostolopoulou and Papadimitriou, 2004; Fan and Pfitzenmaier, 2002; O'Hagan and Harvey, 2000; Webb and Carter, 2001). Some studies focused on specific categories of motives. For example, Cornwell et al. (2001) focused on the branding benefits associated with event sponsorship.

In addition to motives, past research has focused on a number of other variables influencing the sponsorship decision. Some studies examined the factors influencing the choice of potential sponsorship activities (Webb and Carter, 2001) and the criteria when determining the worth of a sponsorship proposal (Farrelly et al., 1997). Farrelly et al. (1997) further studied the 'who does what' within an organisation, that is, the incidence of expenditure related decision-making at various levels of the organizational hierarchy. Still within the area of who makes the decision, O'Hagan and Harvey (2000) and Slack and Bentz (1996) analysed to what extent the decision was made by a group or by an individual. Cornwell et al. (2001) focused on how the degree of active management of sponsorship activities influenced sponsorship decision-making. This included the extent of formality associated with the proposal evaluation and the establishment of a corporate policy regarding what types of activities would be sponsored. Finally, two studies focused on the locus of initiation of sponsorship, that is, whether the sponsorship relationship was initiated by the sponsor or an outside entity (Cornwell et al., 2001; Lamont and Dowell, 2008).

Empirical research on event sponsorship has been drawn from samples of businesses spanning a wide range of industries (e.g. Apostolopoulou and Papadimitriou, 2004; Carter and Wilkinson, 2000; Farrelly et al., 1997; O’Hagan and Harvey, 2000; Shen, 2004; Webb and Carter 2001). A number of studies sought to understand patterns of sponsorship decisionmaking and involvement across different types of companies or sponsorship characteristics. Studies focusing on examining the extent to which the characteristics of the company influence sponsorship include location of the company (Carter and Wilkinson, 2000; Farrelly et al., 1997), size of the business (Carter and Wilkinson, 2000) and type of industry (consumer or industrial: Carter and Wilkinson, 2000; Crowley, 1991). Examples of sponsorship variables include the extent of active management of sponsorship and duration of sponsorship (Cornwell et al., 2001), as well as previous sponsorship experience and timing of the sponsorship decision (Carter and Wilkinson, 2000). 
One further sponsor attribute examined in a number of studies is that of corporate social responsibility (CSR), and in particular firms seeking to demonstrate to (potential) customers their socially responsible credentials. Therefore organisations are increasingly attempting to demonstrate their CSR values through sponsorship (Lacey et al., 2010). If successful, event sponsorships can improve attendees' perceptions of a sponsor (Simmons and Becker-Olsen, 2006). Studies have identified that if attendees perceive the sponsor's CSR to be positive, there will be a positive effect, both direct and indirect, on attendees' purchase intentions (Berger et al., 2007; Brown and Dacin, 1997; Sen and Bhattacharya, 2001). In their study of a North American sporting event (the 2007 Tour de Georgia 667-mile cycling race) Lacey et al. (2010) focused on examining any linkages between attendees' perception of sponsors' commitment to CSR and the attendees' commitment to event sponsor and purchasing intentions. They identified positive linkages between attendees' perceptions of the sponsor's CSR record and attendees' sponsor commitment and purchase intentions. In a further study, Filo et al. (2007) examined the mediation role of CSR on the linkages between event attachment and purchase intent of the event's sponsors' products. Results identify that a positive CSR performance is a factor in corporate image enhancement via consumer attitudes and intent to purchase.

When the geographical scope of empirical sponsorship studies is examined, it is clear that most studies were undertaken in a Western context. For example, O'Hagan and Harvey (2000) studied sponsorship of Irish businesses, Webb and Carter (2001) of Scottish businesses and Farrelly et al., (1997) of North American and Australian businesses. There are virtually no studies on event sponsorship in an Asian context. One of the exceptions is the study by Fan and Pfitzenmaier (2002), who focused on event sponsorship in China.

\section{The drinks industry in India}

India's drinks industry can be split between alcoholic and non-alcoholic sectors. The alcoholic sector is then being split into beer, wines and spirits. While the non-alcoholic sector can be categorised into carbonated drinks, non-carbonated drinks (soft drinks) and hot drinks such as health drinks, tea and coffee. According to Euromonitor International (2009a) and Samajdar (2009), key market growth drivers include favourable demographics, rapid economic growth, rising disposable incomes and increasing social acceptance of alcohol consumption.

Alcohol consumption in India has increased, with expenditure on alcoholic drinks growing 66\% between 2003 and 2008. By 2008, sale of alcoholic drinks in India was in excess of 190 million Rupees (Euromonitor International, 2009a). Consumer expenditure on soft drinks also rose over the same period by over $93 \%$ to a value of over 170,000 million Rupees (Euromonitor International, 2009b). The final sector within the Indian drinks sector is that of hot drinks, including plant based hot drinks, which exhibited a growth of over $40 \%$ between 2003 and 2008, to a value of over 97,000 million Rupees (Euromonitor International, 2009c). Whilst both alcoholic and non-alcoholic sectors have shown high rates of growth, they operate in different social and legal environments. Abstinence from alcohol is a belief deeply rooted in both Indian culture and religion (Ranganathan, 1994). Although the consumption of 
alcohol has risen, the Indian alcoholic drinks sector is heavily regulated and legislated. Prohibition is enshrined in the Constitution of India, and was imposed in 1977 for two years; however states like Mizoram, Manipur and Gujarat remain 'dry'. Others states implement high taxation on alcohol, restrictive licences and "dry" days (Assunta, 2001). Alcohol production is licensed, and although the central government issues guidelines on the sale of alcohol, each state has the discretion to set its own legal age for alcohol consumption (Vadehra, 2005). Alcohol advertising is legally forbidden in India in all types of media. For instance all sectors (beers, wines and spirits) are legally forbidden to advertise on television, radio, newspapers, cinema, point of sale and billboards (World Health Organisation, 2004).

As a result, event marketing is increasing in popularity for long-term brand image building and the humanising of corporate entities. Corporations are increasingly sponsoring events and utilising 'brand ambassadors' to market brands to a focused audience (Gupta, 2003). Despite the growing importance of event sponsorship for event organisers and organisations, there is limited research on event sponsorship decision-making and event sponsorship by specific industries in the public domain (Dolphin, 2003). One exception is the study by Meerabeau et al. (1991), who analysed the external factors influencing sponsorship by the alcohol industry. Specific to this research there is also a dearth of publicly available empirical research examining the Indian drinks industries' sponsorship of events; thus, the need for this research.

\section{Method}

\subsection{Conceptual framework and questionnaire design}

The conceptual framework of the research is provided in Figure 1. At the centre of the framework is the event sponsorship decision-making process. This paper focuses on four variables influencing this decision-making process: motives to sponsor events; reasons not to sponsor events, perceptions of event sponsorship and event sponsorship preferences. These are framed within the outputs of the process, the event sponsorship activity.

\section{INSERT FIGURE 1 HERE}

Motives to sponsor events - While past research has shown that businesses use event sponsorship to achieve a number of benefits, results have failed to provide a clear pattern in relation to which are the most important ones. This is perhaps because the benefits sought by sponsors depend on the type of sponsoring company, products sold and event (Bowdin et al., 2011; Mack, 1999; Walliser, 2003). Given that the range of benefits sought is influenced by many different factors, event managers need to understand the mix of benefits sought by each type of sponsor. The scale contains a combination of corporation or product/brand-related objectives as suggested by Irwin and Asimakopoulos (1992).

Reasons for not sponsoring events - Understanding the constraints affecting a company's involvement in event sponsorship can provide valuable information to the event manager. Once these factors are identified, event managers can work towards overcoming these 
barriers. In this study, an open question was included asking managers to indicate the most important reason for not sponsoring events.

Perceptions of event sponsorship - An examination of the perception about event sponsorship attributes provides valuable information with regards to the mind-set with which event sponsorship decisions are made. A range of statements about event sponsorship were designed following a review of the literature. Statements covered the role of sponsorship within the company's marketing strategy and the attributes of sponsorship, including perceptions regarding the resources required to manage it.

Event sponsorship preferences - Companies can engage in event sponsorship in different ways hence understanding how companies prefer to get involved in event sponsorship can provide valuable 'client' information to event managers. In this research, preferences with regards to form of investment and structure of sponsorship were examined. Structure of sponsorship refers to how many sponsors are involved and, in case of more than one, how hierarchical this relationship is. Sponsors will consider whether sole sponsorship or cosponsorship is preferred (Masterman and Wood, 2006). If sponsorship by more than one sponsor is regarded as acceptable, sponsorship can be tiered whereby sponsors' rights and payment terms may differ according to their level in the structure. Where the structure is flat, all sponsors are acknowledged with the same level of status. The 'form of investment' refers to the means of exchange between the sponsor and the sponsored. Generally speaking, the sponsor can pay for the sponsorship rights in cash, in kind, or a mix of both (Slack and Bentz, 1996). In this study, respondents were asked to indicate their most and least preferred form of investment and structure of sponsorship.

Event sponsorship activity - Gauging event sponsorship activity is essential to identify aspects such as size of the market and explore any differential involvement across sectors. In this study, activity was measured in two ways: (1) spending in event sponsorship and (2) number of events sponsored.

Table 1 provides a summary of the study measures, including how each variable was measured, the scale used and the theoretical source underpinning their inclusion. Before full distribution of the questionnaire, two managers of drinks companies (one from each sector) were asked to fill in the questionnaire and comment on its readability. Some minor changes to the wording and sequence of questions were made.

\section{INSERT TABLE 1 HERE}

\subsection{Data collection and analysis}

In order to understand event sponsorship by the Indian drinks producers, a self-administered questionnaire was used to collect data. Companies often regard information concerning their marketing practices as sensitive and confidential, and consequently are often reluctant to disclose this information. Past research has shown that sending questionnaires to companies is an ineffective method of data collection about event sponsorship, notably when complex information regarding event sponsorship or financial information is requested (Cornwell et 
al., 2001). However previous personal communication with people can be significant factor contributing to actual participation in the survey (Fan and Pfitzenmaier, 2002). Snowball sampling, where the initial pool of respondents is asked to indicate further respondents (Sarantakos, 1998), was used as the sampling method.

One of the authors is employed in the Indian entertainment industry and has developed personal contact with many managers of drink companies. These individuals were approached and asked to fill in the questionnaire. Additionally, they were asked if they knew managers of any other drink companies who could be willing to participate in the study. Due to the snowball sampling nature of the study, it was not possible to control for non-response and consequently estimate the response rate. Companies based in both New Delhi and Mumbai participated in the study. Respondents could opt for a paper or electronic-based questionnaire.

Of the 61 responses, 28 were from non-alcoholic drinks companies, 31 were from alcoholic drinks companies, while two businesses produced both alcoholic and non-alcoholic drinks. These two companies were treated as alcoholic companies because in response to the ban of alcohol advertising in India, some alcoholic drinks businesses have resorted to surrogate branding. This implies that they produce non-alcoholic drinks such as water and soda under the same company name, enabling the non-alcoholic sector to advertise legally.

As far as the characteristics of the respondents are concerned, they were predominantly male (75\%) and around two thirds were under 35 years old. Respondents were mainly sales managers (31.1\%) and marketing managers (31.1\%). The annual turnover of the 61 companies in 2005 was 156 billion Rupees, equivalent to around 1.77 billion GBP (1 $\mathrm{GBP}=88$ Rupees).

Given the different social and legal context in which the alcoholic and non-alcoholic sectors operate, at present it is not clear to what extent these two sectors behave differently in relation to event sponsorship. In this paper, an a-priori segmentation of the drinks industry was adopted by dividing businesses in two groups, according to whether they were involved in the alcoholic drinks market or not. Two statistical tests were used to examine differences between the two sectors. Mann-Whitney was used to identify differences in mean ranks between alcoholic companies and non-alcoholic companies. Logistic regression was employed to identify which motives influence whether a company sells alcoholic drinks or not. Frequencies and mean values were employed to describe the data. Qualitative type data was analysed using the interactive model suggested by Miles and Huberman (1994). Data was reduced by carefully looking at the raw answers and then allocating each to a number of categories developed after the responses were studied (Sarantakos, 1998). 


\section{Results}

\subsection{Perceptions of event sponsorship}

Table 2 provides the frequencies and Mann-Whitney results for the perceptions of event sponsorship. The results show that managers of businesses who sell alcoholic drinks were more likely to agree that event sponsorship requires a lot of managerial expertise $(Z=-2.21$; $\mathrm{p}=0.027)$ and involve a lot of peripheral costs $(Z=-2.10 ; p=0.034)$. An analysis of frequencies indicates that while both type of companies tend to believe that event sponsorship requires managerial expertise, a greater proportion of businesses operating in the alcoholic drinks sector agreed with the statement, and at a higher level of agreement. In relation to the peripheral costs statement, the overwhelming majority of both types of businesses agreed with it $(90 \%)$, however, managers from the alcoholic drinks sector answered more at the strongly agree level than those from non-alcoholic businesses. Non-alcoholic drinks managers were more likely to agree that event sponsorship does not fit the company's marketing objectives $(Z=-2.10 ; p=0.045)$. Looking at the frequencies, nearly half of nonalcoholic drinks managers agreed with the statement, while more than half of alcoholic drinks managers disagreed with it.

No statistical differences were found between the two drinks sectors on the remaining attributes. The results suggest mixed views with regards to the importance of personal relationships and the extent to which sponsorship provides value for money, as only around half of the respondents agreed with both statements. A large proportion of respondents disagreed that event sponsorship was an ineffective tool of marketing, while the majority perceived their company to have enough expertise on managing event sponsorship. Respondents appeared to agree that the event sponsorship industry is cluttered.

INSERT TABLE 2 HERE

\subsection{Motives for sponsoring events}

Table 3 presents the frequencies and the results of Mann-Whitney with regards to the motives to sponsor events. An analysis of the frequencies shows that, with the exception of driving product sales, more than $60 \%$ of managers from alcoholic drinks businesses said that all of the motives were 'very important'. This is in contrast with the non-alcoholic sector, where none of the motives were regarded as 'very important' by more than half of the respondents.

\section{INSERT TABLE 3 HERE}


There were several statistically significant differences between the motives of alcoholic and non-alcoholic drinks businesses, with representatives of the alcoholic sector answering at a higher level of importance (as shown by the higher mean rank) in all cases. For alcoholic drinks businesses, sponsoring events to reach niche audiences $(Z=-3.72 ; p=0.000)$, increase brand awareness $(Z=-2.77 ; p=0.006)$, entertain clients $(Z=-2.12 ; p=0.034)$ and associate with particular lifestyles $(Z=-2.18 ; p=0.029)$ were more important than for non-alcoholic businesses. Similarly, the alcoholic sector regarded gaining advantage over competition $(Z=-$ 2.04; $\mathrm{p}=0.041)$, increasing media coverage $(Z=-4.18 ; \mathrm{p}=0.000)$ and creating goodwill among the community $(Z=-2.01 ; p=0.043)$ as more important than the non-alcoholic sector.

In order to identify which of the nine motives determine whether a company sells alcoholic drinks or not, logistic regression was employed. In the context of this study, logistic regression predicts which of the categories (alcoholic and non-alcoholic) a drinks company is likely to belong to given other information related to that company, in this case, the importance of motives to sponsor events (Field, 2000). The results of the model are summarised in Table 4. Taken together, the log-likelihood values and accuracy of classification suggest that it is appropriate to perform the regression using the 9 predictor variable (Field, 2000). The Nagelkerke's value (a pseudo $\mathrm{R}^{2}$ ) of 0.629 means that nine motives accounted for $63 \%$ percent of the variance in the outcome variable (type of drinks business: alcoholic or non alcoholic) (Field, 2000).

\section{INSERT TABLE 4 HERE}

The bottom half of Table 4 also shows the parameter estimates of the logistic regression analysis. Two motives determined whether a company was an alcoholic or a non alcoholic drinks company. Increased media coverage was the most influential predictor, with an odds ratio of 6.705. This means that an increase of one in the importance of increasing media coverage as a motive to sponsor events increases the likelihood of a company operating in the alcoholic drinks sector by nearly 7 when the importance of other motives remain constant. The odds ratio for reaching niche audiences was 4.405, indicating that if the importance of this motive grows by one, the likelihood of a business belonging to the alcoholic drinks sector increases more than four-fold.

\subsection{Reasons for not sponsoring events}

The main reason for not sponsoring events is displayed in table 5. For drinks businesses in India, the three main reasons for not sponsoring events are, in descending order of frequency, the (1) target audience of the event (2) the perception that traditional forms of promotion are regarded more effective or as offering greater value than event sponsorship and (3) budgetary constraints. Additional important reasons included the profile of the event, the lack of good sponsorship proposals, the difficulty in evaluating sponsorship and no brand exclusivity. The analysis of frequencies for alcoholic and the non-alcoholic businesses suggests clear differences across the two sectors. For non-alcoholic drinks businesses, the three most 
frequent reasons discouraging them from sponsoring events were, in descending order, (1) the effectiveness/greater value of traditional forms of promotion, (2) the profile of the event and (3) the difficulty in evaluating event sponsorship. For the alcoholic sector, the three main factors influencing the non-sponsorship of events were (1) the target audience, (2) budgetary constraints and (3) the lack of good proposals.

INSERT TABLE 5 HERE

\subsection{Sponsorship activity, structure of sponsorship and form of investment}

The results regarding event sponsorship activity, structure of sponsorship and form of investment are shown in Tables 6 (frequencies) and 7 (Mann-Whitney). The event sponsorship spending of the 61 businesses exceeded 55 million GBP, with the drinks industry sponsoring 3,748 events in two years (Table 6). On average, each company sponsored 61 events in the previous two years and spent more than 900 thousand GBP. However, these relatively high values are influenced by 11 businesses (less than $20 \%$ of the sample), which accounted for nearly 90 percent of the sample's total event sponsorship spending. In fact, more than half of the sample appeared to have a modest involvement in event sponsorship. The majority of the sample sponsored twenty or less events in the past two years and accounted for only slightly more than 3 percent (1.76 million GBP) of the annual spending in event sponsorship.

When comparing the two types of companies, 1795 events (47.9\%) were sponsored by nonalcoholic drinks companies and $1953(52.1 \%)$ by those who sold alcohol. The spending of the non-alcoholic sector was much higher than the alcoholic sector. For each 5 pounds of spending in event sponsorship, 4 were made from non-alcoholic drinks companies. No significant differences were found in relation to the total number of events sponsored $(Z=-$ 2.77; $\mathrm{p}=0.006$ ). An additional analysis was undertaken to examine the proportion of turnover spent on event sponsorship. On average, drinks companies spent $2.21 \%$ of their turnover on event sponsorship.

\section{INSERT TABLE 6 HERE}

As far as the structure of sponsorship is concerned, solus structure was clearly the favoured by managers. Not only was this the preferred structure for nearly $80 \%$ of the respondents, but it was the least preferred for only a minority $(8.2 \%)$. The results suggest little difference 
between the preference for tiered and flat structures. Non-alcoholic drinks companies were more likely to have sponsored events in cash than the alcoholic drinks companies (as given by the higher mean rank). No differences were found with regards to sponsoring events inkind and using both in-kind and cash ( $p=.994$ and $p=142$, respectively). The two sectors did not differentiate with regards to preference for form of investment and structure of sponsorship.

\section{INSERT TABLE 7 HERE}

\section{Conclusions}

From an event organiser point of view, sponsors are clients that need to be attracted and satisfied. However, securing sponsorship is becoming more difficult and complex. According to Cornwell et al. (2001, p.45), "participation in sponsorship programs is often a result of the persuasiveness of the to-be-sponsored group". Watt (1998) also noted that the choice of which potential sponsors to approach, is crucial because a misdirected choice can result in failing to secure the desired sponsorship deals. Therefore understanding how sponsors make decisions can help developing tailored sponsorship proposals which is vital for this persuasion to be effective. Focusing on India's drinks industry, this paper aimed to investigate event sponsorship decision-making.

\subsection{Event sponsorship attributes, motivations and activity}

Virtually all companies had been involved in event sponsorship; however there were clear differentiated levels of involvement. More than half had a limited involvement in event sponsorship, while around 1 in 5 was highly involved. In addition, there was a great concentration of sponsorship spending on a small number of companies. Four companies, sponsoring more than 200 events each in the previous two years, accounted for 80 percent of the overall investment in event sponsorship. To a certain extent this mirrors the structure of the drinks industry in India, which is made up of a few large players catering for the mass market and a large number of small players targeting smaller/niche markets (Euromonitor, 2009a,b,c).

The varied relationship with event sponsorship was also visible in the perceived attributes of event sponsorship. There were mixed views with regards to the extent to which sponsoring events was perceived as fitting the company's marketing objectives, providing value for money and being expensive for the company. Sponsorship was viewed as resource demanding by the vast majority of surveyed businesses, whether in terms of managerial expertise or peripheral costs. For half the companies, personal relationships with event organisers influence the decision to sponsor events, suggesting the importance of interpersonal trust and empathy as a pre-condition for obtaining sponsorship in many cases. 
Two of the issues that sponsors will evaluate when deciding whether to sponsor an event or not are the form of investment and the structure of sponsorship (Crompton, 1996; Masterman and Wood, 2006). The results indicate that India's drinks industry favours in-kind sponsorship. While Watt's (1998) assertion that drinks companies can often become major sponsors through bartering is supported; the results suggest an apparent inconsistency between actual and preferred forms of sponsorship. Even though 30 percent of the events sponsored over the two years involved cash payments (partially or fully), an overwhelming majority of managers preferred in-kind sponsorship. One plausible explanation for this discrepancy is the fact that the sponsorship rights of larger events are more valuable than the 'in-kind' value that they can offer. In other cases it may not be feasible to sponsor with drinks at all and thus sponsorship is paid in cash only. There appears to be a clear preference for solus structure of sponsorship. Thus, claims that companies generally prefer to be the single sponsor of an event (Meerabeau et al., 1991) are extended to the drinks industry in India.

Understanding the objectives that sponsors seek to achieve when sponsoring events is very important. Not only does it help event organisers to identify those factors that they need to highlight in the sponsorship proposal, but they know what benefits they have to deliver if they are to keep one important event client satisfied (the sponsor). The difference in mean value between the most important and the fifth most important motive was 0.15 , indicating that the Indian drinks industry uses sponsorship to achieve a range of objectives. Yet, the results suggest that highlighting the opportunities to create goodwill among the community, how the sponsorship will lead to gaining advantage over competitors and how it fosters brand awareness would be the most effective way of securing sponsorship by the drinks industry in India.

Event managers who are able to identify perceived barriers to event sponsorship will be better equipped to design sponsorship proposals that reduce or eliminate these barriers. In this study, seven types of barriers were identified. These barriers relate to three areas: company factors (financial constraints), perceptions about event sponsorship (perception that traditional forms of promotion are more effective than event sponsorship and difficulties in evaluating the effectiveness of event sponsorship) and characteristics of a specific sponsorship opportunity (target audience, profile of the event, lack of good proposals and brand exclusivity).

\subsection{Alcoholic vs. non-alcoholic drinks businesses}

Despite the fact that the promotion of alcohol is heavily regulated and legislated in India, which could lead to a greater use of events for communication, the results suggest that the alcoholic sector was not more likely to sponsor events than the non-alcoholic sector. In fact, in investment volume terms, sponsorship from the non-alcoholic sector is far greater than that of the alcoholic sector. Whilst event organisers will find considerable sponsorship opportunities in both sectors, non-alcoholic drinks businesses appeared to be prepared to spend more per event sponsored. The lower level of average spending per event sponsored by 
the alcoholic sector could be explained by the most important reason for not sponsoring events (target audience). The market for alcoholic drinks is much narrower and thus it can be expected that only a small proportion of events attract the target market for alcoholic drinks (predominantly younger generations). In contrast, all events have the potential to be sponsored by non-alcoholic drinks businesses as these types of products tend to be consumed irrespective of age, gender and religious belief.

In all cases, alcoholic drinks businesses regarded motives more important than the nonalcoholic sector. The alcoholic sector was less likely to agree that sponsoring events did not fit their marketing objectives and hence this consistent higher rating could simply reflect a higher involvement in event sponsorship by the alcoholic sector. From all the differences between the two sectors with regards to motives, two were found to determine which sector the company operates in: reaching niche audiences and increase media coverage. The importance of media coverage in differentiating between alcoholic and non-alcoholic companies is perhaps a result of the strong restrictions to the advertisement of alcoholic drinks taking place in India (as noted earlier, it is not legal to advertise alcoholic drinks in any form of media). Given the existing legal framework, drinks producers are compelled to use communication channels that do not clash with existing legal restrictions. As a result of such restrictions, sponsoring events provides a good alternative in ensuring adequate media coverage as alcoholic brands are allowed to sponsor them. As they freely advertise, nonalcoholic drinks businesses do not need to sponsor events to ensure they can have enough media exposure.

The development of social responsibility credentials is a key means of achieving desired levels of goodwill, which in turn are a pre-condition for achieving organisational goals (Murray and Vogel, 1997). Event sponsorship is a means of fostering corporate social responsibility (Mack, 1999), but at the same time it is a factor that influences the success of event sponsorship (Lacey et al., 2009) and according to the results of this study the drinks sector appears to recognise this. Due to its role in fostering goodwill, social responsibility has become a key driver of corporate marketing strategies (Maignan and Ferrell, 2004), and event sponsorship is no exception. While generating goodwill among the community was more important to alcoholic drinks companies than to non-alcoholic (as given by the MannWhitney test), this motive ranked among the highest for both types of organisation. The negative social effects of alcohol are well documented and hence the importance of this motive for alcoholic drinks companies is not surprising. What is perhaps surprising is that, when compared to the other eight motives, creating goodwill was the most important for nonalcoholic drinks companies. One plausible reason is the potential negative social consequences of some non-alcoholic drinks due to their effect on nutrition and health (Vartanian et al., 2007). In India in particular, there has been controversy about the health risks of soft drinks, with the sale of products of some of the biggest producers being banned in some states (Guardian, 2006).

In summary, the two sectors were different with regards to the motives for sponsoring events, the reasons for not sponsoring events and sponsorship in cash. This suggests that a tailored 
approach to making event sponsorship proposals is desirable according to the sector the sponsor operates in. For event managers, sponsorship requests involving drinks in-kind and offering a solus sponsor deal are more likely to succeed irrespective of whether they are operating in the alcohol or non-alcohol sectors.

\subsection{Implications for practice}

Several implications for practice can be suggested from the findings. From the results it is clear that event sponsorship has established itself as tool within the integrated marketing communications strategy (Sneath et al., 2005) of drinks companies, irrespective of legislative restrictions to alcohol advertisement. Therefore, event managers will find equally good sponsorship opportunities in the alcoholic and non-alcoholic sectors. However, a large proportion of the event sponsorship money appears to be concentrated on a handful of players. One obvious strategy is to nurture good, long-term, strategic relationships with these few larger drinks businesses in order to gain a share of the existing sponsorship money. However, given the high concentration of sponsorship money on a few companies, event managers could find themselves in a low bargaining position (Porter, 1997). The alternative is to work towards expanding the sponsorship market by persuading smaller organisations, who at present have little or no involvement in event sponsorship, of its benefits and encourage them to spend more on it. In either case, a thorough understanding of how each type of organisation makes event sponsorship decisions will facilitate the creation and development of fruitful commercial relationships between event organisers and drinks businesses.

The results also provide event managers with a road map for producing better event sponsorship proposals. Drinks businesses will be more willing to take on sponsorship opportunities that involve sponsorship in-kind, offer solus sponsorship/brand exclusivity. A range of benefits appear to be sought and proposals should demonstrate how the event will deliver on these benefits. Creating goodwill among the community emerged and the single most important motive for both sectors. Events should develop social responsibility credentials and not only emphasise this aspect in their sponsorship proposal, but align the event's social responsibility policy with that of the sponsors to create synergies. This could be materialised by including in the sponsorship proposal ideas of specific activities the event plans to undertake that could contribute to the sponsor's social responsibility agenda. Event managers need to undertake background work to make sure their event's overall profile and target audience fits those of the potential sponsoring brand. Besides these event specific issues, event managers also need consider the context in which event sponsorship decisions are made, such as a manager's perception of event sponsorship, notably with regards to the effectiveness of events as marketing tools.

While the two sectors are similar in many ways, the results indicate that event managers need to approach alcoholic and non-alcoholic businesses differently, notably in terms of the benefits they should offer the sponsor. Event organisers who are able to persuade sponsors 
within the alcoholic sector that their event reaches niche audiences sought by them, and that the event will attract high levels of media coverage, will be in a better position to secure sponsorship from this sub-sector of the drinks industry.

\subsection{Further research}

Whilst this study provides an understanding of the sponsorship decisions and involvement of the drinks businesses in India, future researchers are encouraged to extend this work in a number of ways. One of the important features of this investigation was the focus on a nonwestern business context. As discussed earlier, the results suggest a close relationship between the business context and the decision-making of drinks businesses. Hence, future research could give greater consideration to this relationship. While this paper has compared the sponsorship activity and decision-making according to the type of drinks sold (companies that sell and do not sell alcohol), other variables could be used in future studies including the size of the company and involvement in sponsorship (number of events sponsored and investment). The other obvious lead will be to replicate this study in different contexts (e.g. other industries, other countries). Future research could also explore the influence of the events' target market on the decision to sponsor, such as type(s) of event sponsored.

This study focused on India, one of the alcohol consuming countries with the most restricting laws on alcohol advertising. However, restrictions to alcohol advertising are by no means unique to India. Many other Asian countries such as Thailand (Patton, 2006) have fairly extensive restrictions to alcohol advertising. In Europe, several countries have imposed legal bans on alcohol advertising, while in others self-imposing bans through voluntary agreements prevail (Institute of Alcohol Studies, 2010). Thus, while the results of this study cannot be directly transferred to other contexts, they may be useful for event managers in the many countries where alcohol advertising is constrained by law or have industry self-regulating codes. These research leads, if followed, will result in a better understanding of the sponsorship decision-making process, benefiting event management theory and improving sponsorship practice.

\subsection{Contribution to knowledge}

If one assumes that sponsors within an industry are not alike, it is important to identify specific patterns within that industry. Previous studies on sponsorship have found that the type of firm influences the motives behind event sponsorship (e.g. Apostolopoulou and Papadimitriou, 2004; Carter and Wilkinson, 2000). This paper emphasised the importance of understanding intra-industry patterns in addition to inter-industry patterns (addressed by some previous studies e.g. Carter and Wilkinson, 2000; Crowley, 1991), as the sponsorship 
decision-making process can vary according to the type of products sold, especially in industries which have sub-sectors which are heavily regulated such as the drinks industry.

Some previous studies on sponsorship have focused on the drinks industry. For example, Meerabeau et al. (1991) reviewed the level of involvement of the drinks industry in event sponsorship through the analysis of secondary data. Other studies have addressed sponsorship by the drinks industry from an ethical (McDaniel et al., 2001) or health (Maher, et al., 2006) perspective. Whilst studies about sponsorship by the drinks industry are not new, this is one of the first to do it from a marketing point of view, where the sponsor is viewed as a client of the event. Moreover, in the context of India, there appears to be no research on event sponsorship. Thus, this paper augments the existing research on sponsorship in the drinks industry, and provides an insight into the Indian context.

\section{References}

Aaker, D. A. (1991), Managing Brand Equity, The Free Press, New York, NJ.

Allen, J., O'Toole, W., McDonnell, I. and Harris, R. (2010), Festivals and Special Events Management $5^{\text {th }}$ ed., Wiley, Milton, Qld.

Amis, J., Slack, T. and Berret, T. (1997), "Sport sponsorship as distinctive competence", European Journal of Marketing, Vol. 33 Nos. 3/4, pp. 250-272.

Apostolopoulou, A. and Papadimitriou, D. (2004), “Welcome home': motivations and objectives of the 2004 Grand National Olympic sponsors”, Sport Marketing Quarterly, Vol. 13 No. 4, pp. 180-92.

Assunta, M. (2001), "Impact of alcohol consumption on Asia", The Globe, available at: http://www.ias.org.uk/resources/publications/theglobe/globe200103-04/g1200103-04_p4.html (accessed September 17, 2009).

Batra, R., Ramaswamy, V., Alden, D. L., Steenkamp, J- B. and Ramachander, S. (2000), "Effects of brand local and non-local origin on consumer attitudes in developing countries". Journal of Consumer Psychology, Vol. 9 No. 2, pp. 83-95.

Berger, I. E., Cunningham, P. H. and Drumwright, M. E. (2007), "Mainstreaming corporate social responsibility: developing markets for virtue", California Management Review, Vol. 49 No. 4, pp. 132-157.

Bowdin, G., McDonnell, I., Allen, J. and O’Toole, J. (2011), Event Management $3^{\text {rd }}$ ed., Elsevier ButterworthHeinemann, Oxford.

Brown, T. J, and Dacin, P. A. (1997), "The company and the product: corporate associations and consumer product responses", Journal of Marketing, Vol. 61, pp. 68-84.

Carter, L. and Wilkinson, I. (2000), "Reasons for sponsoring the Sydney 2000 Olympic Games" in Proceedings of the ANZMAC Annual Conference. Gold Coast, Queensland, pp. 175-181.

Chernatony, L., McDonald, M. and Wallace, E. (2011), Creating Powerful Brands $4^{\text {th }}$ ed., ButterworthHeinemann, Oxford.

Cornwell, T. B. and Maignan, I. (1998), “An international review of sponsorship research”, Journal of Advertising, Vol. 27 No. 1, pp. 1-21.

Cornwell, T., Roy, D. and Steinard II, E. (2001), "Exploring managers' perceptions of the impact of sponsorship on brand equity". Journal of Advertising, Vol. 30 No. 2, pp. 41-51.

Crompton, J. (1996), "The potential contributions of sports sponsorship in impacting the product adoption process”. Managing Leisure, Vol. 1, pp. 199-212. 
Crowley, M. (1991), "Prioritising the sponsorship audience". European Journal of Marketing, Vol. 25 No. 11, pp. 11-21.

Das, G. (2001), "India's growing middle class", The Globalist, available at: www.theglobalist.com/DBWeb/StoryId.aspx?StoryId=2195 (Accessed August 15, 2008).

Dhillon, A. (2005), “India's new rich go on spending spree". The Sunday Times www.timesonline.co.uk/tol/news/world/article376778.ece (Accessed August 15, 2008).

Dolphin, R. (2003), “Sponsorship: perspectives on its strategic role”, Corporate communications: an International Journal, Vol. 8 No. 3, pp. 137-186.

Euromonitor, (2009a), Alcoholic drinks in India. Euromonitor, London.

Euromonitor, (2009b), Soft drinks in India. Euromonitor, London.

Euromonitor, (2009c), Hot drinks in India. Euromonitor, London.

European Sponsorship Association, (2007), European Sponsorship Survey. European Sponsorship Association.

Fan, Y. and Pfitzenmaier, N. (2002), "Event sponsorship in China", Corporate Communications: An International Journal, Vol. 7 No. 2, pp. 110-116.

Farrelly, F., Quester, P. and Burton, R. (1997), "Integrating sports sponsorship into the corporate marketing functions: an international comparative survey", International Marketing Review, Vol. 14 No. 3, pp. 170-192.

Farrelly, F., Quester, P. and Mavondo, F. (2003), "Collaborative communication in sponsor relations", Corporate communications: an International Journal, Vol. 8 No. 2, pp. 128-138.

Field, A. (2000), Discovering statistics. Using SPSS for Windows: Advanced techniques for beginners, Sage, London.

Guardian (2006), "India bans soft drinks in pesticides row", available at: http://www.guardian.co.uk/environment/2006/aug/07/food.business, (accessed 02 January 2011)

Gupta, S. (2003), "Event marketing: issues and challenges”, IIMB Management Review, June, pp. 87-96.

Gwinner, K.P. (1997), “A model of image creation and image transfer in event sponsorship", International Marketing Review, Vol. 14 No. 3, pp. 145-158.

Hosmer, D. W. And Lemeshow, S. (2000), Applied Logistic Regression, 2nd ed., John Wiley, New York.

Institute of Alcohol Studies, (2010), IAS Factsheet. Alcohol \& Avertising, available at: http://www.ias.org.uk/resources/factsheets/advertising.pdf, (accessed 02 January 2011).

International Chamber of Commerce, (2003), International code on sponsorship, available at: http://www.iccwbo.org/policy/marketing/id926/index.html, (accessed September 17, 2009).

Irwin, R. and Asimakopoulos, M. (1992), “An approach to the evaluation and selection of sports sponsorship proposals”, Journal of Sports Marketing Quarterly, Vol. 1 No. 2, pp. 43-51.

Kazmin, A. (2009), "India's GDP growth slows sharply to 5.3\%”, Financial Times, available at: www.ft.com/cms/s/0/0dcbb3e8-0492-11de-8166-000077b07658.html?nclick check=1, (accessed April 18, 2009).

Keller, K.L. (1993), “Conceptualizing, measuring, and managing customer-based brand equity”, Journal of Marketing, Vol. 57 No. 1, pp. 1-22.

Keller, K. L. (2007), Strategic Brand Management 3rd ed.. Pearson, Harlow.

Khairullah, D. and Khairullah, Z. (2005), "A study of the extent of westernisation in India magazine advertisements", Asia Pacific Journal of Marketing and Logistics, Vol. 17 No. 2, pp. 2-15.

Lacey, R., Close, A. and Finney, R. (2010), "The pivotal roles of product knowledge and corporate social responsibility in event sponsorship effectiveness", Journal of Business Research, Vol. 63 No. 11, pp. 12221228.

Lamont, M. and Dowell, R. (2008),"A process model of small and medium enterprise sponsorship of regional sport tourism event", Journal of Vacation Marketing, Vol. 14 No. 3, pp. 253-266.

Mack, R. (1999), "Event sponsorship: an exploratory study of small business objectives, practices and perceptions", Journal of Small Business Management, Vol. 37 No. 3, pp. 25-30. 
Maher, A., Wilson, N., Signal, L. and Thomson, G. (2006), "Patterns of sports sponsorship by gambling, alcohol and food companies: an Internet survey", BMC Public Health, Vol. 6, pp. 95-103.

Maignan I. and Ferrell, O.C. (2004), "Corporate Social Responsibility and Marketing: An Integrative Framework", Journal of the Academy of Marketing Science, Vol. 32 No. 1, pp. 3-19.

McDaniel, S., Kinney, L., and Chalip, L. (2001), “A Cross-Cultural Investigation of the Ethical Dimensions of Alcohol and Tobacco Sport Sponsorships”, Teaching Business Ethics, 5, pp. 307-330.

Masterman, G. and Wood, E. (2006), Innovative Marketing Communications: Strategies for the Event Industry, Elsevier Butterworth-Heinemann, Oxford.

Meenaghan, T. (1983), “Commercial sponsorship”, European Journal of Marketing, Vol. 17 No. 7, pp. 5-13.

Meehaghan, T. (1991), "Role of sponsorship in the marketing communication mix", International Journal of Advertising, Vol. 10 No. 1, pp. 35-48.

Meenaghan, T. (2001), "Sponsorship and advertising: a comparison of consumer perceptions", Psychology \& Marketing, Vol. 18 No. 2, pp. 191-215.

Meerabeau, E., Gillet, R., Kennedy, M., Adeoba, J., Byass, M. and Taby, K. (1991), "Sponsorship and the drinks industry in the 1990s", European Journal of Marketing, Vol. 25 No. 11, pp. 39-56.

Miles, M. and Huberman, A. M. (1998), Qualitative data analysis, $2^{\text {nd }}$ ed.. Sage, London.

Murray, K. And Vogel C. (1997), "Using a Hierarchy-of-Effects Approach to Gauge the Effectiveness of Corporate Social Responsibility to Generate Goodwill Toward the Firm: Financial versus Nonfinancial Impacts", Journal of Business Research, 38, pp. 141-159.

Neale, L., Filo, K. and Funk, D. (2007), “Corporate social responsibility and sport event sponsorship", paper presented at the ANZMAC conference, 3-5 December 2007, University of Otago, Dunedin, New Zealand.

O’Hogan, J. and Harvey, D. (2000), "Why do companies sponsor arts events? Some evidence and a proposed classification”, Journal of Cultural Economics, Vol. 24 No. 3, pp. 205-224.

Parvatiyar, A. and Sheth, J. N. (1997), "Paradigm shift in interfirm marketing relationships, emerging research issues", Research in Marketing, Vol. 13 No. 3, pp. 233-256.

Patton, D. (2006), Alcohol firms fight ad ban in Thailand, available from: http://www.apfoodtechnology.com/Industry-drivers/Alcohol-firms-fight-ad-ban-in-Thailand, (accessed 02 January 2010).

Porter, M. (1997) "Competitive strategy", Measuring Business Excellence, Vol. 1 No 2, pp.12 - 17

Ranganathan, S. (1994), “Alcohol in the Third World”, World Health Forum, Vol. 15 No. 3, pp. 226-227.

Roy, D. P. and Cornwell, T. B. (2003), "Brand equity's influence on responses to event sponsorships", Journal of Product \& Brand Management, Vol. 12 No. 6, pp. 377-393.

Samajdar, S. (2009), "An overview of the beverages segment", FnBNews, available at: http://www.fnbnews.com/article/detarchive.asp?articleid=25151\&sectionid=39; (accessed June 28, 2009)

Sarantakos, S. (1998), Social Research, Palgrave, New York.

Sen, S. and Bhattacharya, C. B. (2001), "Does doing good always lead to doing better? Consumer reactions to corporate social responsibility", Journal of Marketing Research, Vol. 38 No. 2, pp. 225-43.

Shen, W. (2004), "A comparative study on corporate sponsorships in Asia and Europe", Asia Europe Journal, Vol. 2 No. 2, pp. 283-295.

Simmons, C. J. and Becker-Olsen, K. L. (2006), "Achieving marketing objectives through social sponsorships", Journal of Marketing, Vol. 70 No. 4, pp. 154-69.

Sinha, D. (2007), "The changing mindset of a billion minds - mapping the emerging of India and its implication for brands and businesses", paper presented at the ESOMAR Asia Pacific Conference, Kuala Lumpur, March 2007, available at: http://www.warc.com, (accessed April 20, 2009).

Skinner, B, and Rukavina, V. (2003), The Complete Guide to Event Sponsorship, Wiley, New York.

Slack, T. and Bentz, L. (1996), "The involvement of small businesses in sport sponsorship", Managing Leisure, Vol. 1 No. 3, pp. 175-184.

Sneath, J., Finney, R. and Close, A. (2005), "An IMC approach to event marketing: the effects of sponsorship and experience on customer attitudes", Journal of Advertising Research, Vol. 45 No. 4, pp. 373-381. 
The World Fact Book, (2009), India, available at: www.cia.gov/library/publications/the-worldfactbook/print/in.html, (accessed April 22, 2009).

Tripodi, J. (2001), "Sponsorship - A Confirmed Weapon in the Promotional Armoury", International Journal of Sports Marketing \& Sponsorship, March/April, pp. 1-20

Vadehra, S. (2005) "Advertising to children in India", Young Consumers: Insight and Ideas for Responsible Marketers, Vol. 6 No. 1, pp. 75-78.

Van der Wagen, L. and Carlos, B. (2005), Event management for tourism, cultural, business and sporting events, Pearson Prentice Hall, Upper Saddle River, New Jersey.

Vartanian, L., Schwartz, M. and Brownell, K. (2007), "Effects of soft drink consumption on nutrition and health: A systematic review and meta-analysis", American Journal of Public Health, Vol. 97 No. 4, pp. 667675 .

Walliser, B. (2003), "An international review of sponsorship research: extension and update", International Journal of Advertising, Vol. 22 No. 1, pp. 5-40.

Watt, D. (1998), Event Management in Leisure and Tourism, Longman, Harlow.

Webb, J. and Carter, S. (2001), "Sponsorship activities and the small firms sector", Managing Leisure, Vol. 6 No. 3, pp. 168-179.

Weilbacher, W. M. (1995), Brand Marketing, NTC Business Books, Chicago, Il.

World Bank (2006), India: country data profile, available at: http://web.worldbank.org, (accessed August 15, 2008).

World Health Organisation, (2004), Alcohol and Substance Abuse in India, available at: www.searo.who.int/LinkFiles/Alcohol and Substance abuse India.pdf, (accessed September 17, 2009). 


\section{Tables}

\subsection{Table 1}

Table 1: Summary of study measures

\begin{tabular}{|c|c|c|c|}
\hline VARIABLE & MEASUREMENT & SCALE & AUTHORS \\
\hline Attributes & $\begin{array}{l}\text { Event sponsorship: Effectiveness } \\
\text { as tool of marketing; extent of } \\
\text { clutter in the industry; extend of } \\
\text { managerial expertise required; } \\
\text { how expensive is for the } \\
\text { company; value for money } \\
\text { provided; fit with marketing } \\
\text { objectives; extent of peripheral } \\
\text { costs associated }\end{array}$ & $\begin{array}{l}5 \text { point Likert } \\
\text { scale }\end{array}$ & $\begin{array}{l}\text { Allen } \text { et al. (2010); Bowdin } \\
\text { et al. (2011); Cornwell, Roy } \\
\text { and Steinard II (2001); } \\
\text { Lamont and Dowell (2008); } \\
\text { O'Hagan and Harvey } \\
\text { (2000); Slack and Bentz } \\
\text { (1996) }\end{array}$ \\
\hline Motives & $\begin{array}{l}\text { Drive product sales; Reach niche } \\
\text { audiences; Increase brand } \\
\text { awareness; Increasing } \\
\text { merchandising opportunities; } \\
\text { Corporate hospitality; Associate } \\
\text { products with particular lifestyles; } \\
\text { Gain advantage over competitors; } \\
\text { Increase media coverage; Create } \\
\text { goodwill among the community }\end{array}$ & $\begin{array}{l}4 \text { point } \\
\text { importance scale }\end{array}$ & $\begin{array}{l}\text { Amis et al. (1997), Ashill et } \\
\text { al. (2001), Bowdin et al. } \\
\text { (2011), Crompton (1996), } \\
\text { Dolphin (2003), FitzGerald } \\
\text { and Arnott (2000), Mack } \\
\text { (1999), Masterman and } \\
\text { Wood (2006), Skinner and } \\
\text { Rukavina (2003), Tripodi } \\
\text { (2001) }\end{array}$ \\
\hline $\begin{array}{l}\text { Reasons for } \\
\text { not sponsoring }\end{array}$ & Open answer question & & \\
\hline $\begin{array}{l}\text { Form of } \\
\text { investment }\end{array}$ & Cash; Products; Both & $\begin{array}{l}\text { Ranking: most } \\
\text { important \& } \\
\text { least important }\end{array}$ & Slack and Bentz (1996) \\
\hline $\begin{array}{l}\text { Sponsorship } \\
\text { structure }\end{array}$ & $\begin{array}{l}\text { Solus structure; Tiered structure; } \\
\text { Flat structure }\end{array}$ & $\begin{array}{l}\text { Ranking: most } \\
\text { important \& } \\
\text { least important }\end{array}$ & $\begin{array}{l}\text { Allen et al. (2010), } \\
\text { Masterman and Wood } \\
(2006)\end{array}$ \\
\hline $\begin{array}{l}\text { Event } \\
\text { sponsorship } \\
\text { activity }\end{array}$ & $\begin{array}{l}\text { Number of events sponsored; Size } \\
\text { of investment in event } \\
\text { sponsorship }\end{array}$ & $\begin{array}{l}\text { Actual number } \\
\text { and value }\end{array}$ & Authors \\
\hline
\end{tabular}




\subsection{Table 2}

Table 2: Attributes of event sponsorship (frequencies and Mann-Whitney)

\begin{tabular}{|c|c|c|c|c|c|c|c|c|c|c|}
\hline & \multirow[b]{2}{*}{ Mean (SD) } & \multicolumn{5}{|c|}{ Frequencies } & \multicolumn{4}{|c|}{ Mann-Whitney } \\
\hline & & SD & D & $\mathbf{U}$ & $\mathbf{A}$ & $\mathbf{S A}$ & $\begin{array}{l}\text { Mean } \\
\text { Rank }\end{array}$ & $\mathbf{U}$ & $\mathbf{Z}$ & Sig \\
\hline \multicolumn{11}{|c|}{ Event sponsorship requires a lot of managerial expertise } \\
\hline All & $4.11(0.90)$ & 0.0 & 8.2 & 9.8 & 44.3 & 37.7 & & & & \\
\hline Non-Alcoholic & $3.86(0.93)$ & 0.0 & 10.7 & 17.9 & 46.4 & 25.0 & 25.95 & 320.5 & -2.21 & .027 \\
\hline Alcoholic & $4.33(0.82)$ & 0.0 & 6.1 & 3.0 & 42.4 & 48.5 & 35.29 & & & \\
\hline \multicolumn{11}{|c|}{ Events sponsorship requires a lot of peripheral costs } \\
\hline All & $4.33(0.79)$ & 0.0 & 4.9 & 4.9 & 42.6 & 47.5 & & & & \\
\hline Non-Alcoholic & $4.21(0.57)$ & 0.0 & 0.0 & 7.1 & 64.3 & 28.6 & 26.32 & 331 & -2.10 & .036 \\
\hline Alcoholic & $4.42(0.94)$ & 0.0 & 9.1 & 3.0 & 24.2 & 63.6 & 34.97 & & & \\
\hline \multicolumn{11}{|c|}{ Sponsoring events does not fit my marketing objectives } \\
\hline All & $3.04(1.35)$ & 11.5 & 31.1 & 19.7 & 16.4 & 21.3 & & & & \\
\hline Non-Alcoholic & $2.67(1.28)$ & 9.1 & 21.2 & 21.2 & 21.2 & 27.3 & 35.09 & 327 & -2.10 & .045 \\
\hline Alcoholic & $3.36(1.34)$ & 14.3 & 42.9 & 17.9 & 10.7 & 14.3 & 26.18 & & & \\
\hline \multicolumn{11}{|c|}{ Personal relationship with organisers play a large part in deciding whether or not to sponsor the event } \\
\hline All & $3.16(1.36)$ & 14.8 & 23.0 & 9.8 & 36.6 & 16.4 & & & & \\
\hline Non-Alcoholic & $3.21(1.32)$ & 10.7 & 25.0 & 14.3 & 32.1 & 17.9 & 31.55 & 447 & -.232 & .816 \\
\hline Alcoholic & $3.12(1.41)$ & 18.2 & 21.2 & 6.1 & 39.4 & 15.2 & 30.53 & & & \\
\hline \multicolumn{11}{|c|}{ Event sponsorship is an ineffective tool of marketing } \\
\hline All & $2.07(1.11)$ & 37.7 & 34.4 & 14.8 & 9.8 & 3.3 & & & & \\
\hline Non-Alcoholic & $2.18(1.02)$ & 28.6 & 39.3 & 17.9 & 14.3 & 0.0 & 33.61 & 389 & -1.11 & .266 \\
\hline Alcoholic & $1.97(1.19)$ & 45.5 & 30.3 & 12.1 & 6.1 & 6.1 & 28.79 & & & \\
\hline \multicolumn{11}{|c|}{ Event sponsorship provides value for money } \\
\hline All & $3.18(1.20)$ & 11.5 & 16.4 & 27.9 & 31.1 & 13.1 & & & & \\
\hline Non-Alcoholic & $3.36(1.16)$ & 10.7 & 7.1 & 31.1 & 35.7 & 14.3 & 33.61 & 389 & -1.09 & .276 \\
\hline Alcoholic & $3.03(1.24)$ & 12.1 & 24.2 & 24.2 & 27.3 & 12.1 & 28.79 & & & \\
\hline \multicolumn{11}{|c|}{ We have enough expertise on managing event sponsorship } \\
\hline All & $3.92(0.97)$ & 0.0 & 14.8 & 6.6 & 50.8 & 27.9 & & & & \\
\hline Non-Alcoholic & $3.75(1.00)$ & 0.0 & 21.4 & 0.0 & 60.7 & 17.9 & 28.14 & 382 & -1.260 & .208 \\
\hline Alcoholic & $4.06(0.93)$ & 0.0 & 9.1 & 12.1 & 42.4 & 36.6 & 33.42 & & & \\
\hline \multicolumn{11}{|c|}{ Event sponsorship is very expensive for my company } \\
\hline All & $2.77(1.24)$ & 14.8 & 34.4 & 21.3 & 18.0 & 11.5 & & & & \\
\hline Non-Alcoholic & $2.75(1.24)$ & 14.3 & 39.3 & 10.7 & 28.6 & 7.1 & 30.68 & 453 & -.13 & .893 \\
\hline Alcoholic & $2.79(1.27)$ & 15.2 & 30.3 & 30.3 & 9.1 & 15.2 & 31.27 & & & \\
\hline \multicolumn{11}{|c|}{ Event sponsorship industry is cluttered } \\
\hline All & $3.93(1.11)$ & 3.3 & 11.5 & 9.8 & 39.3 & 36.1 & & & & \\
\hline Non-Alcoholic & $3.96(1.04)$ & 3.6 & 7.1 & 10.7 & 46.4 & 32.1 & 30.82 & 457 & -.077 & .939 \\
\hline Alcoholic & $3.91(1.18)$ & 3.0 & 15.2 & 9.1 & 33.3 & 39.4 & 28.79 & & & \\
\hline
\end{tabular}

Notes: SD - Strongly Disagree; D - Disagree; U - Uncertain; A - Agree; SA - Strongly Agree 


\subsection{Table 3}

Table 3: Motives for sponsoring events (frequencies and Mann-Whitney)

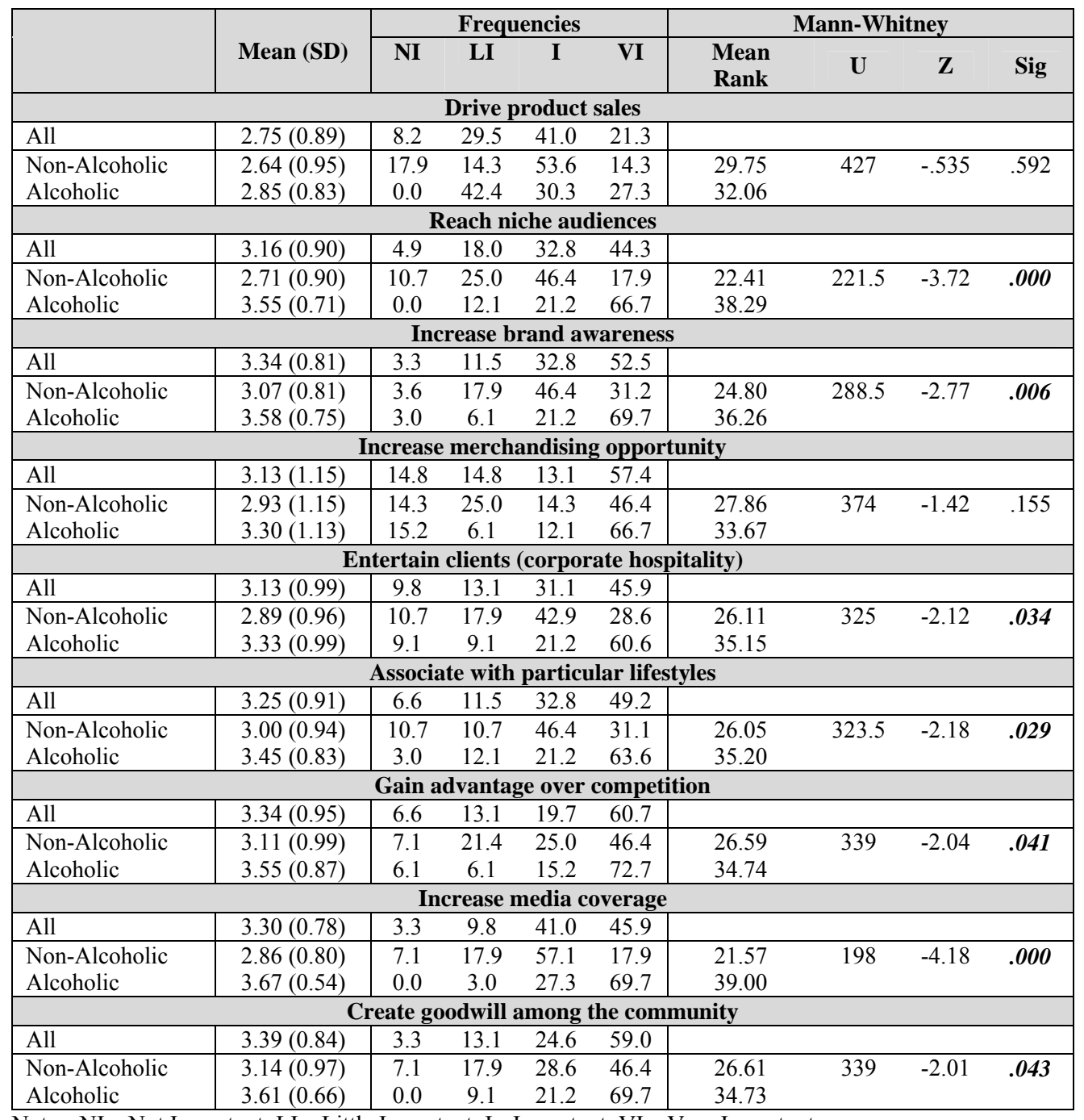

Notes: NI - Not Important; LI - Little Important; I - Important; VI - Very Important 


\subsection{Table 4}

Table 4: Model summary and impact of the bundle of motives on the type of business (alcoholic and non-alcoholic)

\begin{tabular}{|c|c|c|c|c|c|c|c|}
\hline \multicolumn{8}{|c|}{$(\mathrm{N}=59)$} \\
\hline & $x^{2}$ & Df & $p$ & $\beta$ & S.E. & Wald & $\operatorname{Exp}(ß)$ \\
\hline Initial -2 Log likelihood & 80.959 & & & & & & \\
\hline Model -2 Log likelihood & 37.433 & & & & & & \\
\hline Cox \& Snell R2 & .470 & & & & & & \\
\hline Nagelkerke R2 & .629 & & & & & & \\
\hline Hosmer \& Lemeshow (2000) & 5.703 & 8 & 0.680 & & & & \\
\hline Drive product sales & & 1 & .835 & -.086 & .551 & .025 & .917 \\
\hline Reach niche audiences & & 1 & .013 & 1.483 & .596 & 6.182 & 4.405 \\
\hline Increase brand awareness & & 1 & .139 & .981 & .663 & 2.194 & 2.668 \\
\hline Increase merchandising opportunity & & 1 & .736 & -.129 & .355 & .132 & .879 \\
\hline Entertain clients (corporate hospitality) & & 1 & .819 & .119 & .521 & .052 & 1.126 \\
\hline Associate with particular lifestyles & & 1 & .920 & -.050 & .497 & .010 & .951 \\
\hline Gain advantage over competition & & 1 & .619 & -.303 & .610 & .247 & .739 \\
\hline Increase media coverage & & 1 & .011 & 1.923 & .745 & 6.529 & 6.705 \\
\hline Create goodwill among the community & & 1 & .383 & .559 & .640 & .761 & 1.748 \\
\hline Constant & & 1 & .000 & -14.218 & 4.055 & 12.294 & .000 \\
\hline
\end{tabular}

\subsection{Table 5}

Table 5: Reasons for not sponsoring events (Frequencies)

\begin{tabular}{lccccccc}
\hline & \multicolumn{2}{c}{ All } & \multicolumn{2}{c}{ Non Alcoholic } & \multicolumn{2}{c}{ Alcoholic } \\
\hline & $\mathrm{N}$ & $\%$ & $\mathrm{~N}$ & $\%$ & $\mathrm{~N}$ & $\%$ \\
\hline Target audience & 17 & 27.9 & 3 & 10.7 & 14 & 42.4 \\
Traditional forms of promotion more effective or & 10 & 16.4 & 8 & 28.6 & 2 & 6.1 \\
offer greater value & & 14.8 & 2 & 7.1 & 7 & 21.2 \\
Budgetary constraints & 9 & 13.1 & 5 & 17.9 & 3 & 9.1 \\
Profile of the event & 8 & 7 & 11.5 & 3 & 10.7 & 4 & 12.1 \\
Lack of good proposals & 5 & 8.2 & 5 & 17.9 & 0 & 0.0 \\
Evaluation of sponsorship is difficult & 4 & 6.6 & 1 & 3.6 & 3 & 9.1 \\
Brand exclusivity & 1 & 1.6 & 1 & 3.6 & 0 & 0.0 \\
Other & 61 & 100 & 28 & 100 & 33 & 100 \\
Total & & & & & & \\
\hline
\end{tabular}




\subsection{Table 6}

Table 6: Number of events sponsored, form of investment and structure of sponsorship (Frequencies)

\begin{tabular}{|c|c|c|c|c|c|c|}
\hline & \multicolumn{2}{|c|}{ All } & \multicolumn{2}{|c|}{ Non Alcoholic } & \multicolumn{2}{|c|}{ Alcoholic } \\
\hline \multicolumn{7}{|c|}{ Spending in event sponsorship according to events sponsored* } \\
\hline & $£ \mathrm{M}$ & $\%$ & $£ \mathrm{M}$ & $\%$ & $£$ & $\%$ \\
\hline $1-5$ & 0.265 & 0.5 & 0.142 & 0.3 & 0.122 & 1.1 \\
\hline $6-10$ & 0.875 & 1.6 & 0.415 & 0.9 & 0.460 & 4.2 \\
\hline $11-20$ & 0.623 & 1.1 & 0.182 & 0.4 & 0.440 & 4.0 \\
\hline $21-100$ & 5.168 & 9.3 & 4.015 & 9.0 & 1.153 & 10.5 \\
\hline+101 & 48.920 & 87.6 & 40.085 & 89.4 & 8.835 & 80.2 \\
\hline Total & 55.851 & 100 & 44.839 & 100 & 11.012 & 100 \\
\hline \multicolumn{7}{|c|}{ Percentage of turnover spend on event sponsorship } \\
\hline & $\mathrm{n}$ & $\%$ & $\mathrm{n}$ & $\%$ & $\mathrm{n}$ & $\%$ \\
\hline \multicolumn{7}{|l|}{ None } \\
\hline \multicolumn{7}{|c|}{ Number of events sponsored } \\
\hline & $\mathrm{n}$ & $\%$ & $\mathrm{n}$ & $\%$ & $\mathrm{n}$ & $\%$ \\
\hline None & 1 & 1.6 & 1 & 3.6 & 0 & 0.0 \\
\hline $1-5$ & 12 & 19.7 & 5 & 17.9 & 7 & 21.2 \\
\hline $6-10$ & 10 & 16.4 & 4 & 14.3 & 6 & 18.2 \\
\hline $11-20$ & 11 & 18.0 & 3 & 10.7 & 8 & 24.2 \\
\hline $21-100$ & 16 & 26.2 & 10 & 35.7 & 6 & 18.2 \\
\hline+101 & 11 & 18.1 & 5 & 17.8 & 6 & 18.2 \\
\hline Total & 61 & 100 & 28 & 100 & 33 & 100 \\
\hline \multicolumn{7}{|c|}{ Number of events sponsored according to form of sponsorship } \\
\hline Cash & 527 & 14.1 & 340 & 18.9 & 187 & 9.6 \\
\hline In-Kind & 2615 & 69.8 & 1166 & 65.0 & 1449 & 74.2 \\
\hline Both & 606 & 16.2 & 289 & 16.1 & 317 & 16.2 \\
\hline Total & 3748 & 100 & 1795 & 100 & 1953 & 100 \\
\hline \multicolumn{7}{|c|}{ Most preferred form } \\
\hline Cash & 2 & 3.3 & 0 & 0.0 & 2 & 6.1 \\
\hline In-Kind & 55 & 90.2 & 24 & 85.7 & 31 & 93.9 \\
\hline Both & 4 & 6.6 & 4 & 14.3 & 0 & 0.0 \\
\hline Total & 61 & 100 & 28 & 100 & 33 & 100 \\
\hline \multicolumn{7}{|c|}{ Least preferred form } \\
\hline Cash & 51 & 83.6 & 22 & 78.6 & 29 & 87.9 \\
\hline In-Kind & 3 & 4.9 & 1 & 3.6 & 2 & 6.1 \\
\hline Both & 7 & 11.5 & 5 & 17.9 & 2 & 6.1 \\
\hline Total & 61 & 100 & 28 & 100 & 33 & 100 \\
\hline \multicolumn{7}{|c|}{ Most preferred structure } \\
\hline Solus Structure & 48 & 78.7 & 23 & 82.1 & 25 & 75.8 \\
\hline Tiered Structure & 6 & 9.8 & 1 & 3.6 & 5 & 15.2 \\
\hline Flat Structure & 7 & 11.5 & 4 & 14.3 & 3 & 9.1 \\
\hline Total & 61 & 100 & 28 & 100 & 33 & 100 \\
\hline \multicolumn{7}{|c|}{ Least preferred structure } \\
\hline Solus Structure & 5 & 8.2 & 2 & 7.1 & 3 & 9.1 \\
\hline Tiered Structure & 26 & 42.6 & 13 & 46.4 & 13 & 39.4 \\
\hline Flat Structure & 30 & 49.9 & 13 & 46.4 & 17 & 51.5 \\
\hline Total & 61 & 100 & 28 & 100 & 33 & 100 \\
\hline
\end{tabular}

* Values may not add to total due to rounding 


\subsection{Table 7}

Table 7: Number of events sponsored, form of investment and structure of sponsorship (Mann-Whitney)

\begin{tabular}{|c|c|c|c|c|c|}
\hline & \multicolumn{2}{|c|}{ Mean Rank } & \multirow{2}{*}{$\mathbf{U}$} & \multirow{2}{*}{$\mathbf{Z}$} & \multirow{2}{*}{ Sig } \\
\hline & Non-Alcoholic & Alcoholic & & & \\
\hline \multicolumn{6}{|c|}{ Number of events sponsored } \\
\hline Total of events* & 31.95 & 30.20 & 436 & -.384 & .701 \\
\hline \multicolumn{6}{|c|}{ Number of events sponsored according to form of investment } \\
\hline Cash & 37.09 & 25.83 & 292 & -2.509 & .012 \\
\hline In-Kind & 31.02 & 30.98 & 462 & -.007 & .994 \\
\hline Both & 34.59 & 27.95 & 362 & -1.467 & .142 \\
\hline \multicolumn{6}{|c|}{ Preference for form of investment } \\
\hline Cash & 29.68 & 32.12 & 425 & -.833 & .405 \\
\hline In-Kind & 32.25 & 29.94 & 427 & -.981 & .327 \\
\hline Both & 30.73 & 31.23 & 454 & -.162 & .871 \\
\hline \multicolumn{6}{|c|}{ Preference for structure of sponsorship } \\
\hline Solus Structure & 30.43 & 31.48 & 446 & -.334 & .738 \\
\hline Tiered Structure & 32.88 & 29.41 & 410 & -.848 & .397 \\
\hline Flat Structure & 29.82 & 32.00 & 429 & -.598 & .598 \\
\hline
\end{tabular}

Notes: * exact number of events used to perform the test

\subsection{Figure 1}

Figure 1: Conceptual framework

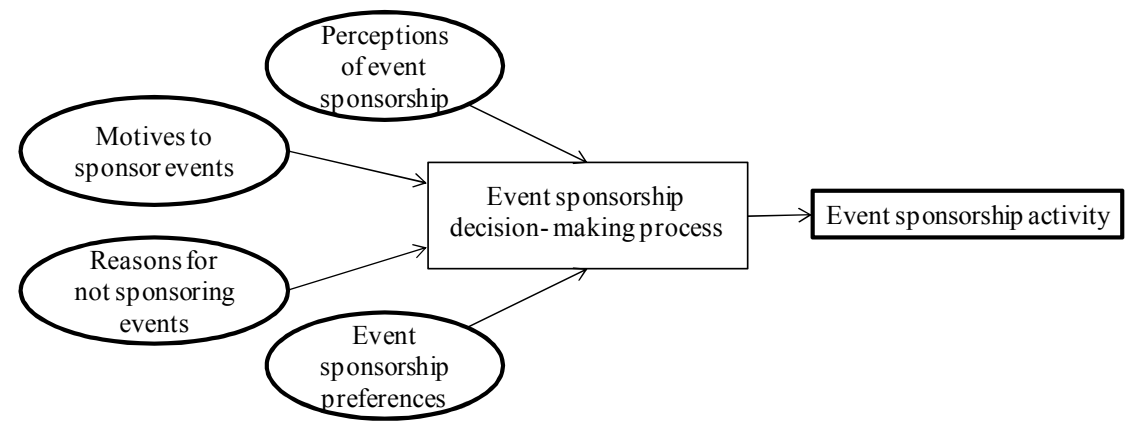

